\title{
Tropical storm off Myanmar coast sweeps reefs in Ritchie's Archipelago, Andaman
}

\author{
P. Krishnan • Grinson-George • N. Vikas • \\ Titus-Immanuel • M. P. Goutham-Bharathi • \\ A. Anand • K. Vinod Kumar • S. Senthil Kumar
}

Received: 23 February 2012 / Accepted: 8 October 2012

(C) Springer Science+Business Media Dordrecht 2012

\begin{abstract}
The reefs in some islands of Andaman and Nicobar suffered severe damage following a tropical storm in the Bay of Bengal off Myanmar coast during 13-17 March 2011. Surveys were conducted at eight sites in Andaman, of which five were located in the Ritchie's Archipelago where maximum wind speeds of $11 \mathrm{~ms}^{-1}$ was observed; and three around Port Blair which lay on the leeward side of the storm and had not experienced wind speeds of more than $9 \mathrm{~ms}^{-1}$. Corals
\end{abstract}

P. Krishnan $(\bowtie) \cdot$ Grinson-George · Titus-Immanuel •

M. P. Goutham-Bharathi

Marine Research Laboratory,

Central Agricultural Research Institute,

Port Blair 744101 Andaman and Nicobar Islands, India

e-mail: krishnanars@yahoo.com

N. Vikas

Dive India Ltd,

Havelock, South Andaman 744 122, India

A. Anand

Regional Remote Sensing Centre-Central,

National Remote Sensing Centre (ISRO),

Nagpur 440 010, India

\section{K. V. Kumar}

Division of Physical Oceanography,

National Institute of Oceanography,

Dona Paula, Goa 403 004, India

\section{S. S. Kumar}

Department of Environment and Forests,

Andaman and Nicobar Administration,

Port Blair 744 101, India in the shallow inshore reefs were broken and dislodged by the thrust of the waves. Significant damage in the deeper regions and offshore reefs were caused by the settlement of debris and sand brought down from the shallower regions. The fragile branching corals (Acropora sp.) were reduced to rubbles and the larger boulder corals (Porites sp.) were toppled over or scarred by falling debris. The reefs on the windward side and directly in the path of the storm winds were the worst affected. The investigation exposes the vulnerability of the reefs in Andaman to the oceanographic features which generally remain unnoticed unless the damage is caused to the coastal habitats.

Keywords Coral reefs - Tropical storm · Surge · Geostrophic currents · Eddies

\section{Introduction}

Coral reefs across the world were affected by the elevated sea surface temperature (SST) during May 2010 and in Andaman the extent of damage was up to $70 \%$ in some islands (Krishnan et al. 2011). The reefs in some islands suffered a severe damage during March 2011 following the tropical storm off Myanmar coast which was observed during a routine reef health monitoring survey. Tropical storms and cyclones frequently occur at latitudes $10-30^{\circ}$ on both sides of the equator and are perhaps the most obvious and frequent 
natural disturbances affecting reef communities (Gardner et al. 2005; Done 1992) at various spatial and temporal scales. A tropical cyclone hit the Myanmar coastline around Irrawaddy Division and Moon State with wind speed up to 50 knots and wave height of 4 $6 \mathrm{~m}$ during 14-16 March, 2011. Around 4000 fishermen were swept into the Andaman Sea from the Pyapon region in Myanmar during the storm (http://www. mizzima.com/news/inside-burma/5054-up-to-4000fishermen-from-pyapon-missing-in-storms). Myanmar's Department of Meteorology and Hydrology reported on March 14, 2011 that the region experienced heavy winds and rain with thunder and lightning. The surge associated with the storm which moved southwards caused significant damage to the reefs in its path.

A number of studies have documented the extent of direct mortality caused by storms at local or regional scales (Gardner et al. 2005; Done 1992). The ecological effects of cyclones on coral reefs have been reviewed by Harmelin-Vivien (1994). The tropical storms cause severe damage to the reefs and their impacts include the removal of reef matrix, scouring and fragmentation (Done 1992; Van-Woesik et al. 1991; Rogers et al. 1991), deposition of loosened material onto beaches above sea level or propelling them into deeper sub-reef environments (Done 1992; Scoffin 1994). The sediments taken into suspension by storm currents lead to burial of reef organisms (Hubbard et al. 1991; Rogers et al. 1991), increase in turbidity, decrease in available light and augmented energy allocation towards the removal of sediment particles (Rogers 1983).

The waves and swell generated following the 1980 hurricane in the regions of Coral reefs of West Hawaii caused extensive damage to corals, with the storm surf destroying zonation pattern, causing dislodgement and breakage of branching corals and leaving reef slope area littered with broken plates of Porites lobata (Dollar 1982). Similar storm related coral reef damages have been documented in French Polynesia in 1982-83 (Harmelin-Vivien and Laboute 1986), Jamaica in 1980 (Woodley et al. 1981) and in Great Barrier Reef of Australia by Cyclone Joy in 1990 (Van-Woesik et al. 1995) and tropical cyclone Ingrid in 2005 (Fabricius et al. 2008).

The Caribbean reefs which were reduced to $17 \%$ following a Hurricane did not recover to pre-storm state for at least 8 years after impact (Gardner et al. 2005). The study on the damage and recovery of coral reefs in
Hawaii over a 20 year period suggests that the reefs are resilient and persisting through geologic time through natural stressors but the increase in anthropogenic activities and their effects tend to make the recovery process more difficult (Dollar and Grigg 2003). Hence, even though episodic events like storms and hurricanes have a profound impact on the reefs, other factors like anthropogenic activities and effects of changing climate have significant bearing on the survival of reefs.

\section{Materials and methods}

The study started after one of the routine reef health monitoring surveys in the last week of March 2011 at South Button Island, a popular dive site in Andaman, where corals were found crushed to rubbles. This lead to a purposive survey during April to September 2011 at eight selected sites in South Andaman viz., South Button Island (12 $13^{\prime} 366^{\prime}$ N $93^{\circ} 01^{\prime} 292^{\prime}$ E), a small island located towards the northern side of Ritchie's Archipelago with reefs extending upto a depth of 24 m; Sebastian's Hill (12 $12^{\circ}$ ' 261" N 93० 02' 404" E), Minerva Ledge ( $12^{\circ} 04^{\prime} 023^{\prime}$ N $93^{\circ} 09^{\prime} 066^{\prime}$ E), Broken Ledge (12 $\left.{ }^{\circ} 06^{\prime} 791^{\prime \prime} \mathrm{N} 93^{\circ} 08^{\prime} 703^{\prime \prime} \mathrm{E}\right)$ and Jackson's Bar (12 $\left.07^{\circ} 410^{\prime \prime} \mathrm{N} 93^{\circ} 09^{\prime} 653^{\prime \prime} \mathrm{E}\right)$, all popular offshore underwater dive sites located in the Ritchie's Archipelago; Red Skin Island ( $11^{\circ} 32^{\prime}$ 23.27" N 92० 35'03.98" E), a popular tourist site under Mahatma Gandhi Marine National Park; North Bay (11 ${ }^{\circ} 42^{\prime} 21.20^{\prime \prime} \mathrm{N} 92^{\circ} 45^{\prime} 15.20^{\prime \prime}$ E) and Chidiyatapu (11 $\left.21^{\circ} 28.00^{\prime \prime} \mathrm{N} 92^{\circ} 42^{\prime} 40.00^{\prime \prime} \mathrm{E}\right)$, sites in Port Blair which are bordered by fringing reefs extending up to a maximum depth of $10 \mathrm{~m}$ (Fig. 1a). After the initial surveys, South Button was selected for further extensive survey. The Island was divided into 7 regions to investigate the extent of damage to the reefs (Fig. 1b).

Field surveys were conducted using Self Contained Underwater Breathing Apparatus (SCUBA), photographs and videos were taken using a digital camera (Canon powershot G11) with an underwater case (Ikelite). Data with respect to coral species that were damaged and depths of damage of reef organisms were collected. Similar data with respect to the study sites collected prior to the incidence of storm were used to determine the extent of disturbance. Based on the qualitative observations made, extent of damage was categorized into nil, moderate and severe, where on a scale of ten, $0-3$ is nil; 4-7 is moderate and 7-10 is severe. 
Fig. 1 a Map of Andaman and Nicobar Islands showing the study sites at Ritchie's Archipelago; (1)

South Button Island; (2) Sebastian hill; (3) Minerva ledge; (4) Broken ledge; (5) Jackson bar; (6) Red Skin; (7) North Bay; (8) Chidyatapu. b Specific locations surveyed around South Button Island a

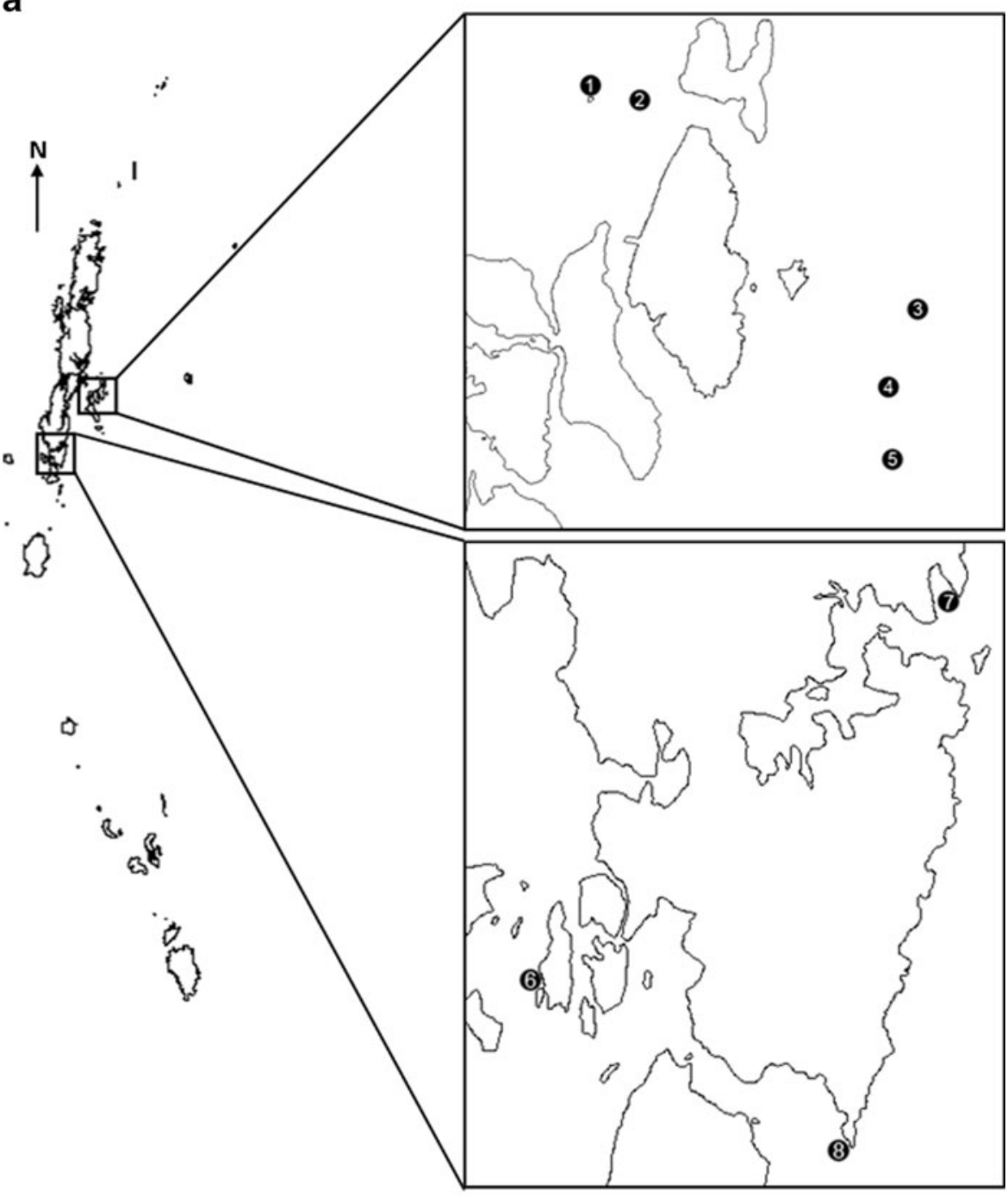

b

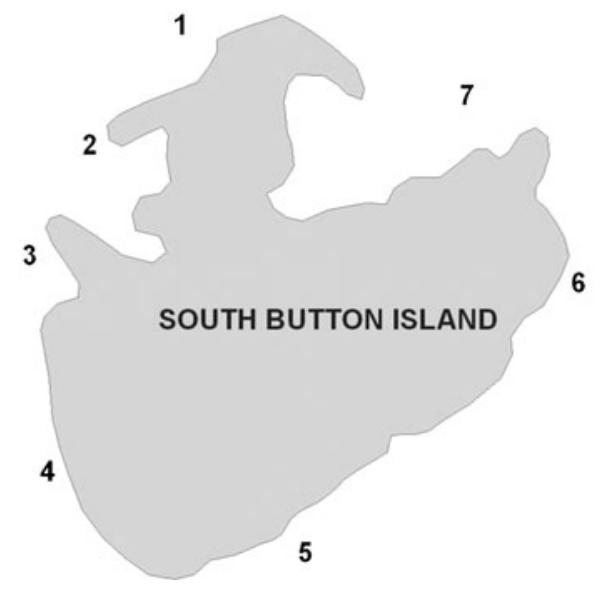


Satellite Altimetry-based Map of Sea Level Anomaly (MSLA) data of Near Real Time (NRT) available with the Archival, Validation and Interpretation of Satellite Oceanographic Data (AVISO) (http://www.aviso.oceanobs.com/en/data/products/ index.html) was used to study the Sea Level Anomaly and Surface Geostrophic currents in the region during 13-23 March 2011. These data sets are prepared by AVISO using Altimetry data from various sensors (Multi-mission products). Sea level anomaly and surface geostrophic current vector data were processed to generate sea level anomaly and current maps using ARC-GIS software with the data for the period 13-23 March 2011. Eddy Kinetic Energy (EKE) was computed from the Zonal and Meridional Geostrophic current vectors.
Weather Research and Forecasting (WRF) modelling system was employed for predicting the storm surge dynamics during the study period. The model domain extends from $90^{\circ} \mathrm{E}$ to $95^{\circ} \mathrm{E}$ and $9^{\circ} \mathrm{N}$ to $15^{\circ} \mathrm{N}$, covering the Andaman group of Islands and the simulation was carried out from 10-19 March 2011 with a resolution of $9 \mathrm{~km}$. The tide pattern during March 2011 was obtained from the automatic tide gauge installed at Marine Hill, Port Blair.

\section{Results}

Large scale disturbances were observed in all the selected study sites in Ritchie's Archipelago (Fig. 2), while the reefs around Port Blair viz., Redskin Island,
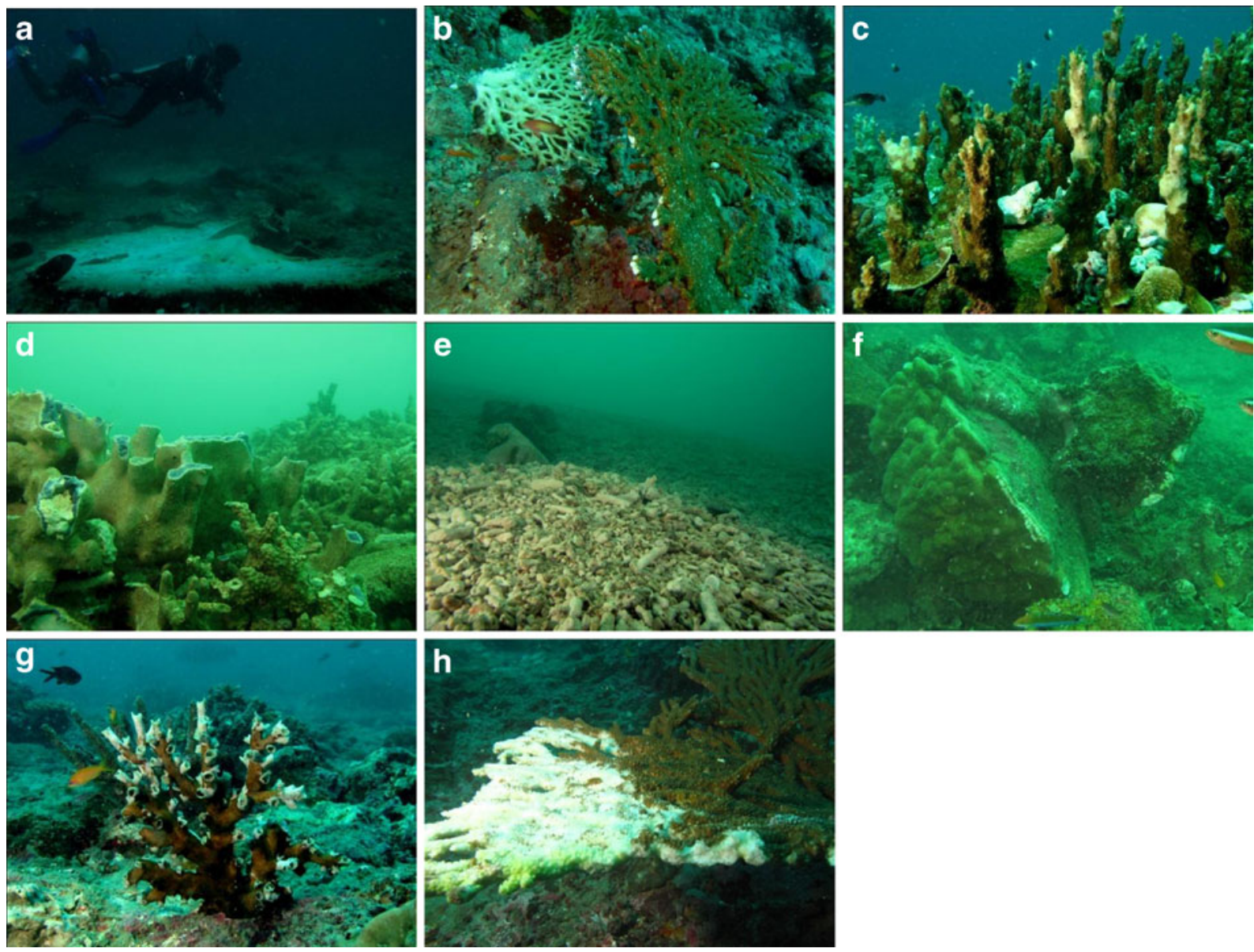

Fig. 2 Damage to corals due to the storm. a A large table coral measuring $3 \mathrm{~m}$ turned over; $\mathbf{b}$ branches broken off a table coral; c debris strewn on top of submassive coral (Montipora sp.) damaging its branches; d broken branches of blue coral
(Heliopora caeurulea); e coral rubble collected at $24 \mathrm{~m}$ depth; f a toppled boulder coral (Porites lobata); $\mathbf{g}$ bleached Tubastrea micrantha, revealing the white skeleton; $\mathbf{h}$ table coral partially bleached at the edges 
North Bay and Chidiyatapu were unaffected. Among the islands affected, there was variation in depths of damage between the islands and also between the locations within an island. Surveys revealed extensive coral damages up to $15 \mathrm{~m}$ depth in the north-eastern region of South Button Island. The dead corals from the previous bleaching events, along the vertical walls of South Button were dislocated.

Table corals (Acropora spp.) were found to have been toppled (Fig. 2a) and some had broken edges (Fig. 2b). The outer-shelf reefs were damaged by the current-swept debris which broke and scarred the branching and plate corals (Fig. 2c, d). The branching corals which were bleached during May 2010 had died subsequently and these dead corals along with those few which were recovering also were washed off by the storm and were piled up at deeper $(24 \mathrm{~m})$ zones (Fig. 2e). At Sebastian Hill, massive corals (Porites lobata) measuring over $2 \mathrm{~m}$ in size and found at depths of 9-11 m were toppled (Fig. 2f). Except for the removal of dead branching corals at 19-22 m, no significant damage was observed at Jackson Bar. At deeper waters $(30 \mathrm{~m})$, sand and rubble were piled under one of the ledges. Surveys conducted at Broken Ledge in depths ranging from 17-23 m showed that the storm has left different patterns of damage on the corals of shallower regions viz., Millipora sp. was broken; Acropora chesterfieldensis was scarred; Tubastrea micrantha had bleached and most colonies had died (Fig. 2g) and the table coral, Acropora hyacinthus was found to be flipped over. At Minerva Ledge several boulder corals (Porites spp.) were broken off at their bases and rolled onto their sides at depths ranging from 9-18 $\mathrm{m}$. The scars on living coral surfaces were attributed to the debris. Some corals belonging to Acroporidae were partially bleached (Fig. 2h), which could be attributed to reduced salinity levels due to the incessant rains as reported by VanWoesik et al. (1995) and Hoegh-Gulberg and Smith (1989).

The storm caused significant damage to the reef associated organisms also. The barrel sponge (Xestospongia testudinaria) (Fig. 3a) and soft corals of Nepthidae (Fig. 3b) at Jackson Bar were partially bleached. Among the survey sites, storm-associated bleaching was common at Jackson Bar, however, it was observed only in few individuals and most of the partially bleached species had a strong chance of recovery. The rock oysters (Ostreidae), usually covered with a thick mat of algae, appeared to have been scrubbed by the storm (Fig. 3c). The surge/storm also dislodged the weak reef associates from their habitat and carried them to the deeper zones along with the coral rubbles (Fig. 3d).
Fig. 3 Effects of storm on coral-associated organisms. a Partially bleached barrel sponge (Xestospongia testudinaria); b partially bleached soft coral (Nephthidae); c rock oysters (Ostreidae) cleaned off algae; $\mathbf{d}$ feather star (Crinoidea) dislodged from its reef habitat
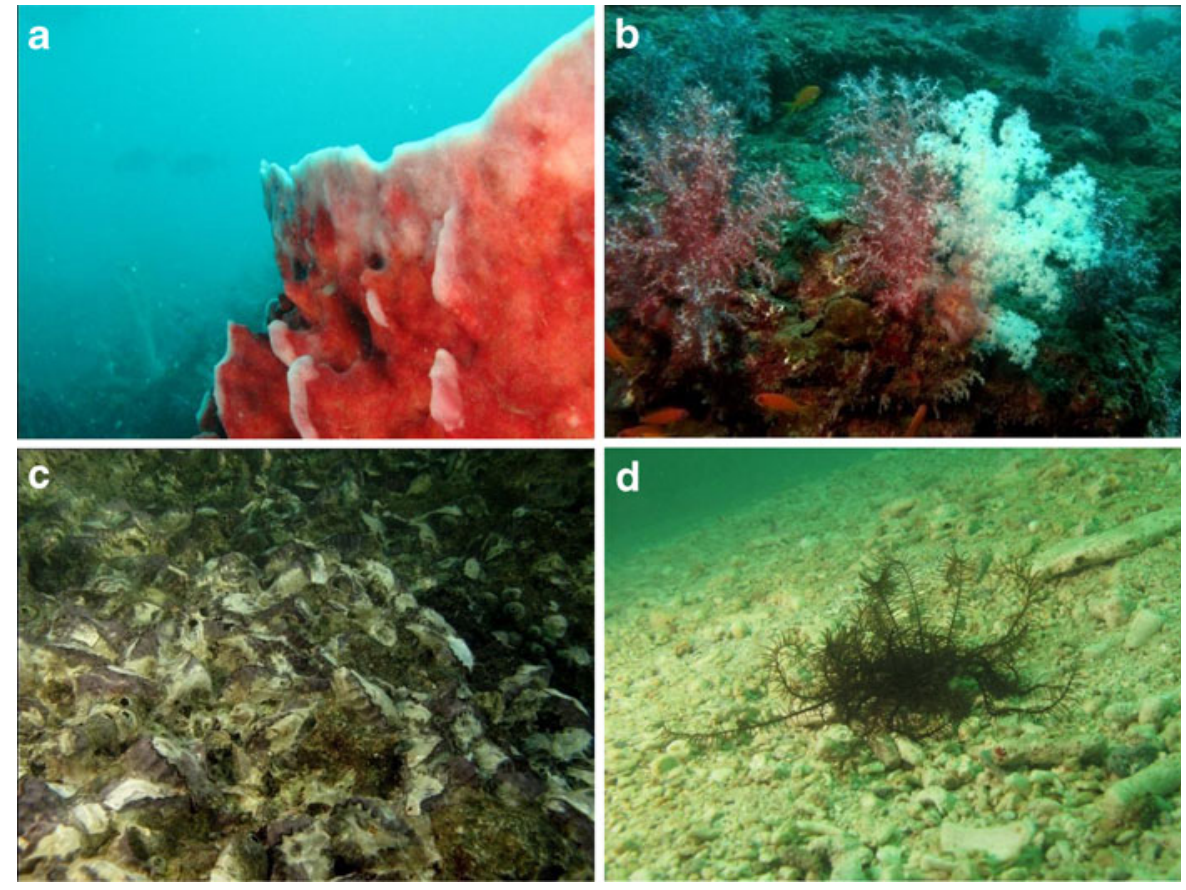
The tide pattern did not show significant change in the amplitude during the period of storm, as recorded from the ATG installed at Port Blair (Fig. 4). The WRF model showed that wind velocities were less than $7 \mathrm{~ms}^{-1}$ till 13 March and gradually increased through 14-15 March 2011 up to about $8 \mathrm{~ms}^{-1}$. The highest wind speeds were recorded on 16 and 17 March reaching up to $11 \mathrm{~ms}^{-1}$ and $10 \mathrm{~ms}^{-1}$ respectively. The speed reduced drastically to $4 \mathrm{~ms}^{-1}$ and below during 18-19 March 2011 indicating the dissipation of the storm winds (Table 1). Studies on wind speed and direction revealed that the prominent wind direction was north-easterly over the Ritchie's Archipelago (Fig. 5).

Map of sea level anomalies (MSLA) and Surface Geostrophic current maps revealed the presence of mesoscale warm core (anti-cyclonic) eddy close to the shores of South and Little Andaman encompassing the areas where damage to reefs is documented. Surface Geostrophic current speeds ranging between 20 and $30 \mathrm{cms}^{-1}$ were observed in the periphery of the eddy (Fig. 6). The eddy persisted during the period of 13-23 March, 2011. The Eddy Kinetic Energy (EKE) was high in Ritchie's Archipelago (Fig. 7).

\section{Discussion}

The comprehensive survey around the South Button Island showed the progression of storm clearly. The damage was more in the northern and northwestern side of the Island, which corroborated with the direction of the storm. The shape of the Island might have partially protected the Northeast reefs where damage at both the surveyed sites was comparatively lesser. Being on the leeward side, the reef of southern region was completely spared of any mechanical damage by the storm (Mumby 1999). A detailed account on the site-wise status of the reef is provided in Table 2. The reefs around Port Blair remained unaffected as the energy of storm would have dissipated and also due to the fact that the sites surveyed were in the leeward side of the storm.

Mesoscale eddies are quite common in the seas surrounding the Andaman and Nicobar Islands, however their presence in such close proximity to the coast as observed in this event has not yet been recorded. Eddies occurring in coral reef areas are known to cause thermal stress related bleaching due to the upwelling associated with the eddy circulation (Jokiel and Coles 1990). Models evaluating the hydrographic effects of eddy on island waters (Farmer and Berg 1989) have explained the dispersal of larvae due to high-velocity shear currents generated by the approaching eddy. Cross-frontal advection has been documented for cold core and warm core eddies (Wiebe and Flierl 1983; Wroblewski and Cheney 1984). Fast currents generated by eddies, tidal and ocean currents and gyres, quite close to coral islands are considered as physical factors that induce local water movements, flush toxins and remove thermal stratification in coral reef locations and hence are assumed as high reliability factors of resistance to coral bleaching (West and Salm 2003). Physical

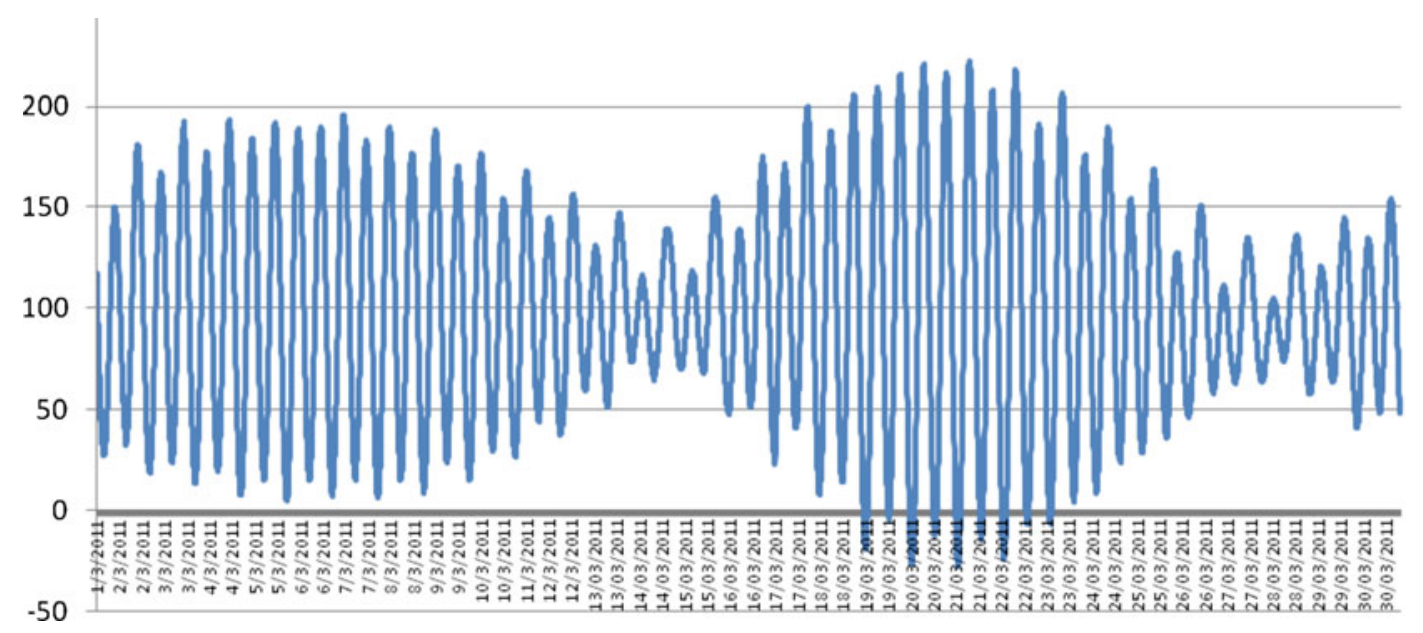

Fig. 4 Tide pattern during March 2011 as recorded from the automatic tide gauge installed at Port Blair 
Table 1 Wind-model estimates over Andaman as determined by WRF Model

\begin{tabular}{lll}
\hline Date & $\begin{array}{l}\text { Mean Wind } \\
\text { Speed }\left(\mathrm{m} \mathrm{s}^{-1}\right)\end{array}$ & Direction \\
\hline 10 Mar 2011 & $6-7$ & Easterly \\
11 Mar 2011 & $5-7$ & Easterly \\
12 Mar 2011 & $4-5$ & North-easterly \\
13 Mar 2011 & $4-5$ & North-easterly \\
14 Mar 2011 & $7-8$ & North-easterly \\
15 Mar 2011 & $7-8$ & North-easterly \\
16 Mar 2011 & $9-11$ & North and North-easterly \\
17 Mar 2011 & $9-10$ & North-easterly \\
18 Mar 2011 & $3-5$ & North-easterly and Easterly
\end{tabular}

damage to the coral reef structures due to eddies is not yet documented. The EKE computed for the present eddy shows high kinetic energy in the area of Ritchie's Archipelago (Fig. 7). Although eddies with high kinetic energy alone are insufficient to cause such extensive damage, the presence of such intensive current activity coupled with the other factors like storm winds and shallow bathymetry in the coral reef areas seem to have a contributory effect especially in transport of the sediments and smothering of coral reefs as observed extensively in this case.

The location of the reef, coral community type and succession stage of coral development are the factors which play an important role in determining the fragility or robustness of the reef (Fabricius et al. 2008). The spatial factors determining vulnerability of a particular coral community are the position of a reef across the continental shelf and their location within a reef. Most of the corals were stripped off the inshore a

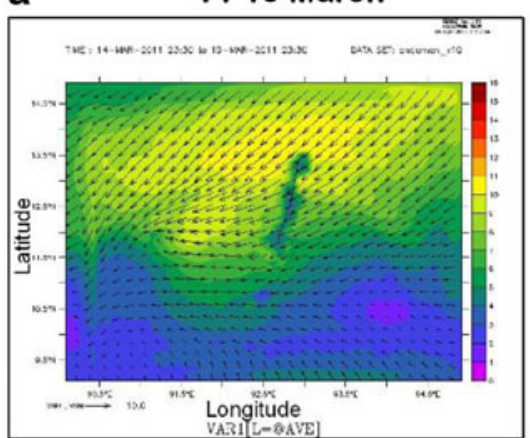

b 15-16 March

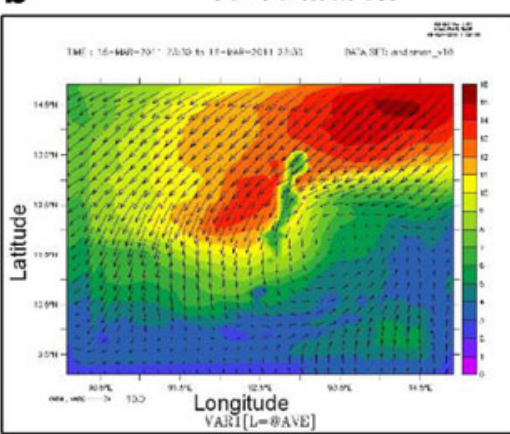

C

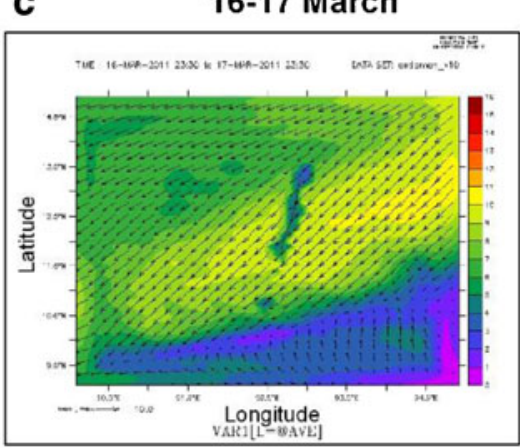

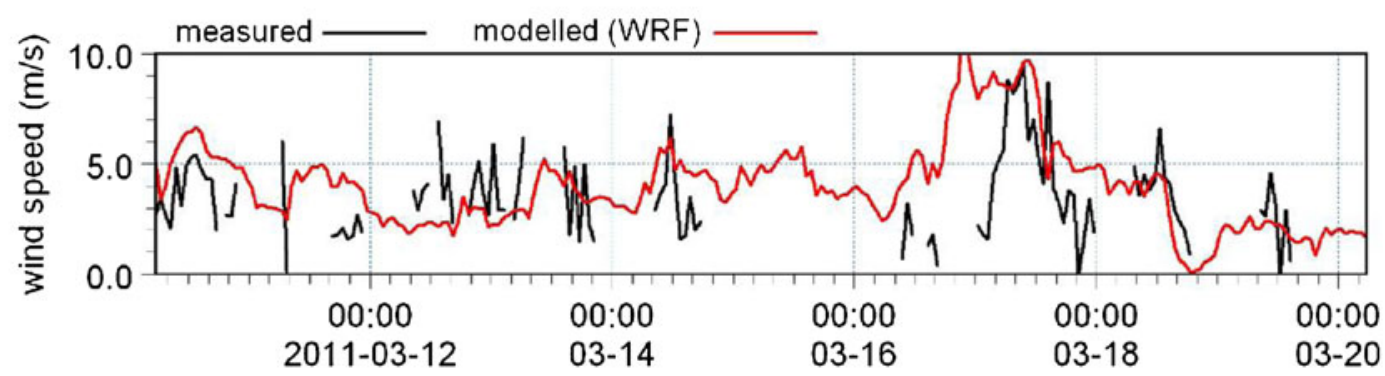

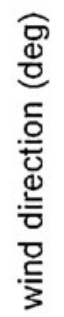

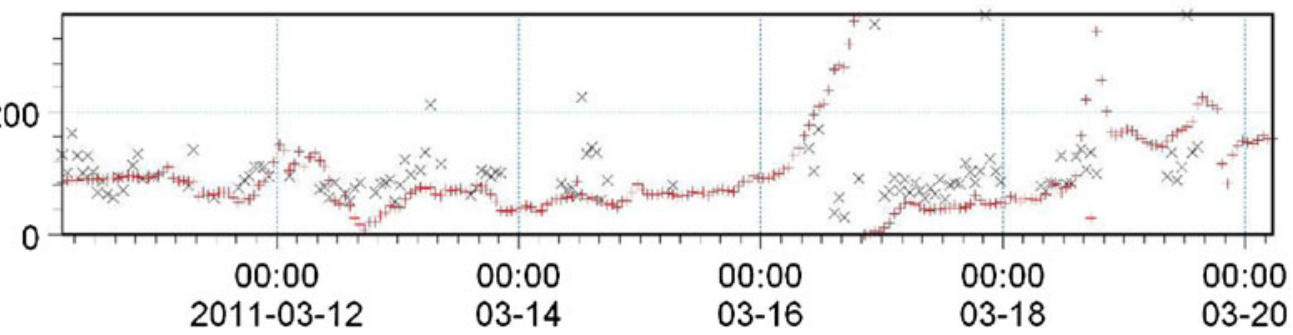

Fig. 5 Wind direction and speed during 12-18 March 2011 derived from the WRF model showing the occurrence of storm surge in South Andaman on 16 March 2011 


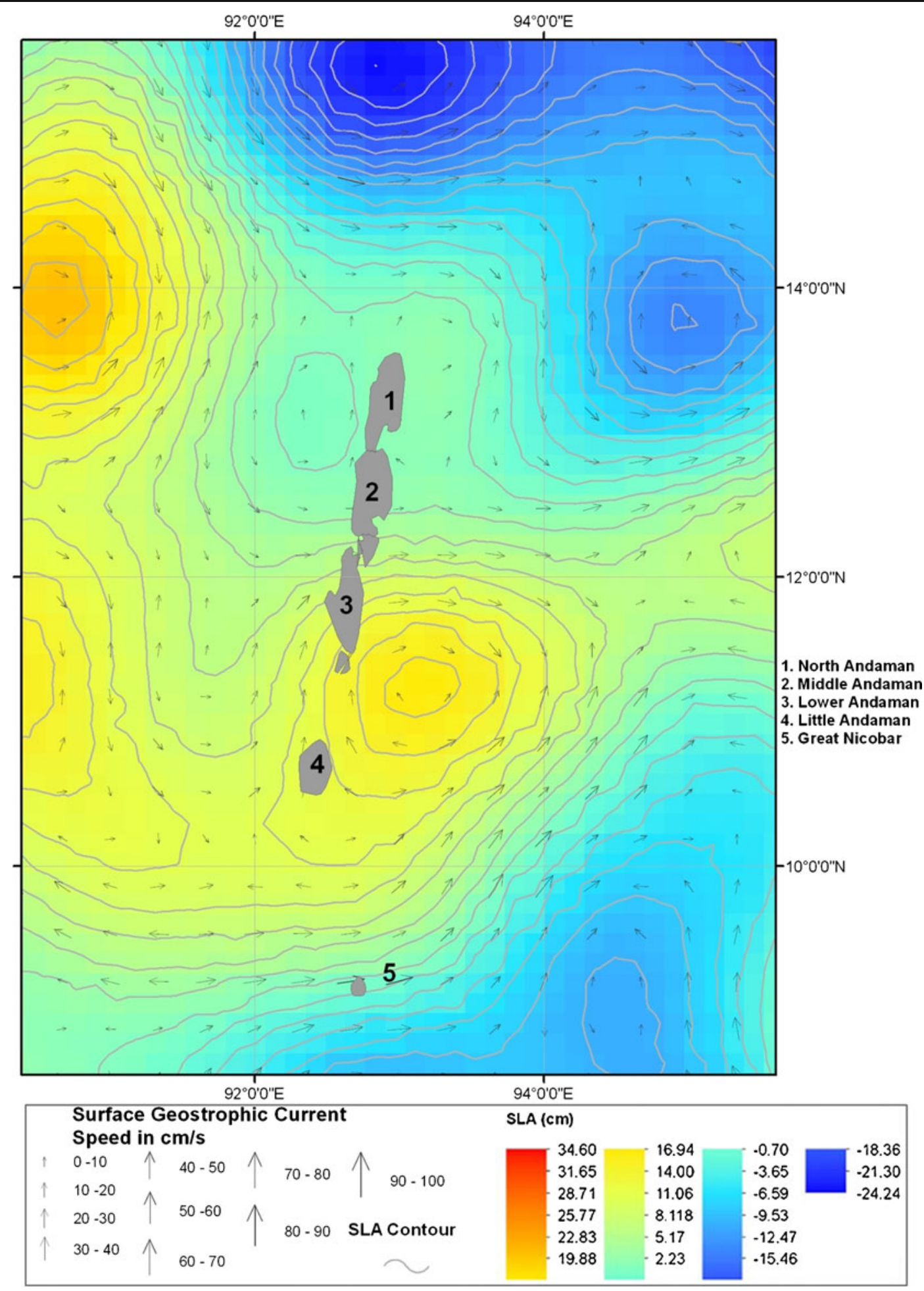

Fig. 6 Sea level anomaly (SLA) and geostrophic currents around Andaman on 13-18 March 2011

reefs (up to $15 \mathrm{~m}$ ) of South Button, which mainly consisted of taller branching and larger table corals of
Acropora spp. and foliose corals (Montipora spp. and Echinopora lamellosa). This damage might be due to 


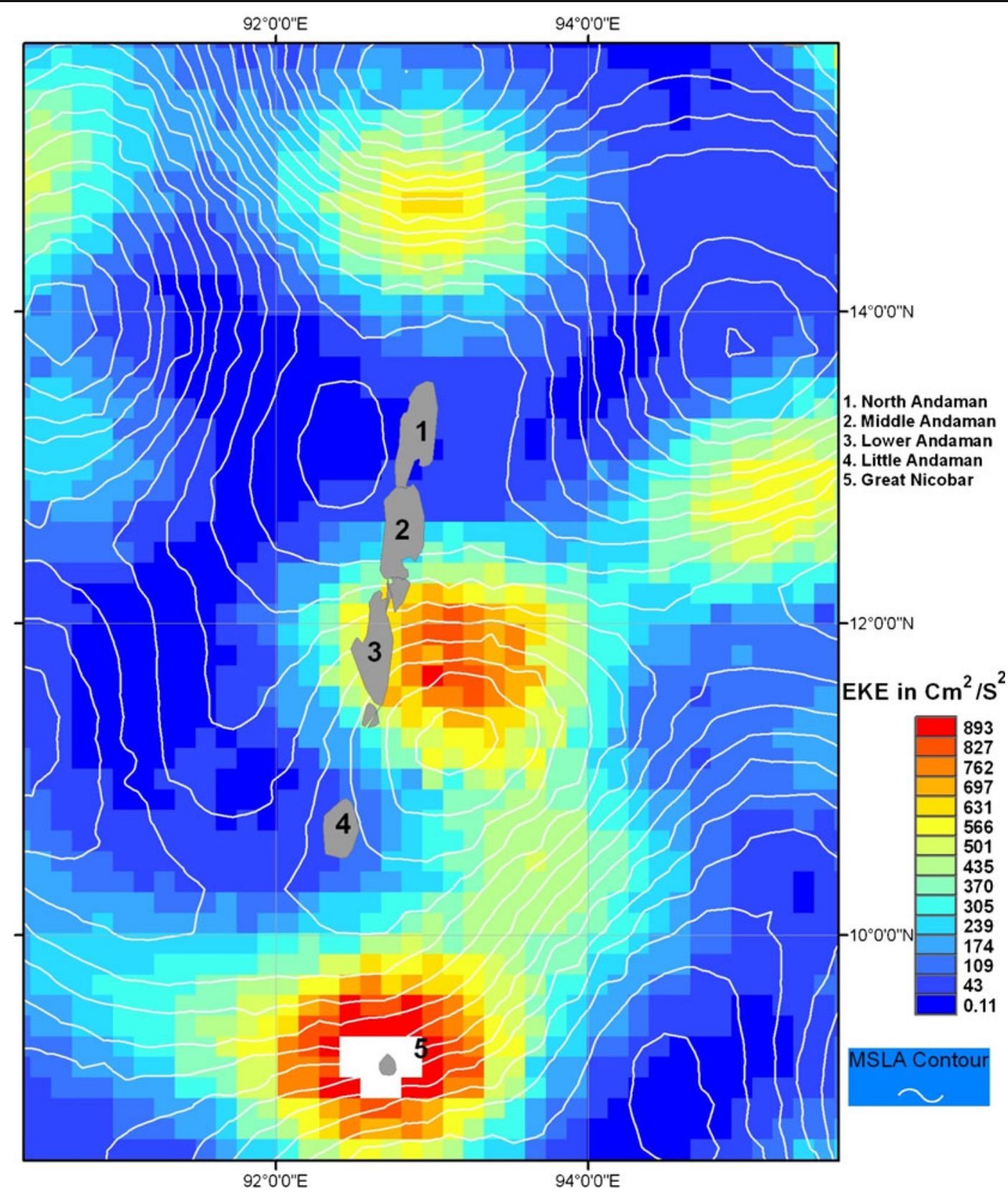

Fig. 7 Eddy kinetic energy (EKE) map showing high kinetic energy zones in the vicinity of the Ritchie's Archipelago

lower skeletal density and weaker reef substrata (more loosely assembled and poorly cemented) of inshore corals than those on offshore reefs due to greater internal bioerosion and fewer crustose coralline algae (Perry and Smithers 2006). It was also observed that the robust offshore reefs of Sebastian Hill, Jackson's Bar, Broken Ledge and Minerva Ledge had comparatively lesser damages to the inshore reefs. In almost all the sites, the effect of the storm was confined to the shallower regions while in the deeper regions, the damage was due to the settlement of debris and sand that had been brought down from the shallower regions.

The type of coral community is another factor that determines the degree of vulnerability of coral reefs. The habitat of coral communities vary across the inshore-offshore gradient in wave exposure, bathymetry, 
Table 2 The status of reefs around the South Button Island

\begin{tabular}{|c|c|c|c|}
\hline Site & Depth (m) & Status of reefs & $\begin{array}{l}\text { Extent of } \\
\text { damage }\end{array}$ \\
\hline Site 1 & $5-6$ & $\begin{array}{l}\text { All the Acropora and other branching corals were totally } \\
\text { stripped off their substratum and reduced to rubbles. }\end{array}$ & Severe \\
\hline Site 2 & $8-10$ & $\begin{array}{l}\text { The corals mainly belonging to Acropora spp. have been } \\
\text { broken and strewn in the entire reef region. A few live } \\
\text { corals (Poritidae and Favidae) were found. }\end{array}$ & Severe \\
\hline Site 3 & $8-9$ & $\begin{array}{l}\text { Massive corals of the genus Porites predominate. The } \\
\text { dead coral skeletons of Acroporidae were found intact. }\end{array}$ & Nil \\
\hline Site 4 & $7-9$ & Favidae and Poritidae were the dominant corals. & Nil \\
\hline Site 5 & $6-8$ & $\begin{array}{l}\text { Mainly covered with short branched Acroporidae. Few } \\
\text { were observed to have been stripped off the substratum ; } \\
\text { broken coral rubble collected at } 2-4 \mathrm{~m} \text { depth }\end{array}$ & Moderate \\
\hline Site 6 & $7-9$ & $\begin{array}{l}\text { Acroporidae predominate. The skeletal remains of the } \\
\text { branching corals which died following } 2010 \text { mass } \\
\text { bleaching were mostly intact with minor damages. }\end{array}$ & Moderate \\
\hline Site 7 & $5-7$ & $\begin{array}{l}\text { Short branched and small Table corals of the genus } \\
\text { Acropora were the predominant corals present here. } \\
\text { Most of the rocks have been completely cleaned off } \\
\text { all coral cover. }\end{array}$ & Severe \\
\hline
\end{tabular}

water clarity and light (Done 1982). Boulder corals and submassive corals are less vulnerable to wave associated damage. Even Acropora spp. with rigid, corymbose and submassive growth forms, complemented by some low, compact branching forms are capable of withstanding the thrust of waves, however in a storm, the light skeletal structure and branches render them fragile and susceptible. South button reef was predominated by Acropora spp. particularly up to $7 \mathrm{~m}$ depth and hence was adversely affected by the storm. Catastrophic damage to delicate corals and the survival of robust massive colonies is common during major storms (Edmunds and Witman 1991) and has important implications because massive corals build the framework of coral reefs (Sheppard 1982).

Massive coral assemblages affected by storms have two responses viz., dislodgement and resistance (Done 1992; Van-Woesik et al. 1991; Done and Navin 1990). It was observed in the current study that the massive corals, Porites lobata, P. lutea and P. solida were less affected in all the reefs. However, in some offshore reefs, corals measuring up to $2 \mathrm{~m}$ in diameter were found to have been dislodged and often pushed downslope. Examination of basal areas of toppled corals suggested that they were already unattached or were only weakly attached to the substratum prior to dislodgement. Tissues brought into contact with the substratum during the fall had died but remaining areas of the colony survived. Similar observations have already been reported (Massel and Done 1993). Some of the corals with larger bases which showed resistance to the waves were scarred by debris falling on them.

Stage of development of the coral community also influences the degree of vulnerability of reef (Fabricius et al. 2008). A reef that has been denuded in recent years (e.g. by cyclonic waves, bleaching, or outbreaks of crown-of-thorns starfish) and is occupied by newly settled young colonies offers little hydrodynamic drag and would be relatively invulnerable (Madin and Connolly 2006). The Andaman reefs which witnessed mass bleaching due to the elevated SST during May 2010 (Krishnan et al. 2011) were dead but were still able to shelter several fishes and other organisms in their structural complexes. When the storm waves lashed at these coral structures they were not able to resist those waves, much like the live branching corals; dead corals being even more vulnerable due to the action of several bioeroders (Glynn 1993). Though the storm left the reef denuded, substrate for colonization by new coral recruits increased (Rogers et al. 1991).

Disturbance plays a central role in the dynamics of a wide variety of ecological communities (Karlson and Hurd 1993; Krummel et al. 1987). Extreme disturbance can reduce diversity and alter community structure by eliminating species (Petraitis et al. 1989; Pickett et al. 1989). In contrast, moderate levels of disturbance may promote local diversity by reducing the abundance of competitively dominant species and 
allowing inferior competitors to persist (Petraitis et al. 1989; Connel 1997). Studies have shown that the abundance of fish and other reef associated organisms decline when reef structures are flattened and such indirect mortality may manifest soon after the storm or years to decades later (Harmelin-Vivien 1994; Wilson et al. 2006).

Island mass effect, unique to oceanic islands, was documented by Doty and Oguri (1956) where they described the increased primary production in the windward side of Oahu island in the Hawaii in contrast to the oligotrophic waters surrounding the island. The ability of coral reefs to flourish in the unproductive environment is attributed to upstream divergence of oceanic currents encountering the island mass effect, complex currents and topographically generated gyres which induce upwelling and favourable productive conditions (Hamner and Hauri 1981). Phytoplankton blooms and subsequent zooplankton abundance are found to help in the recovery of corals bleached due to unfavourable environmental conditions, by promoting feeding (Palardy et al. 2006; Grottoli et al. 2006), delaying their death and increasing the chance of survival of bleached corals (Anthony et al. 2009). Island mass effect is thus considered a critical factor in determining the resilience of coral reefs to bleaching in the face of increased incidence of bleaching events caused directly or indirectly by changing climate. Studies on the island mass effect around the Andaman \& Nicobar Islands are lacking and in the present case, involvement of such a phenomenon in damage to corals is not suspected. Further studies to establish any such phenomenon in the area and possible effects are needed.

The current investigation shows that the diversity of reef organisms have not yet been altered in the study sites except in case of South Button where the reef associates appear to have migrated from the regions damaged to those unaffected. However, the long term impact of this colossal physical damage remains to be seen. In addition to the widely recognized impact of changing climate on the reefs in terms of elevated SST, the study exposes the vulnerability of the island reefs to the oceanographic features which generally go unnoticed unless they directly affect the life or the property of coastal inhabitants.

\section{References}

Anthony, K. R. N., Hoogenboom, M. O., Maynard, J. A., Grottoli, A. G., \& Middlebrook, R. (2009). Energetics approach to predicting mortality risk from environmental stress: a case study of coral bleaching. Functional Ecology, 23, 539-550.

Connel, J. H. (1997). Disturbance and recovery of coral assemblages. Coral Reefs, 16(suppl), 101-113.

Dollar, S. J. (1982). Wave stress and coral community structure in Hawaii. Coral Reefs, 1, 71-81.

Dollar, S. J. \& Grigg, R. W. (2003). Anthropogenic and Natural stresses on coral reefs in Hawaii: A multi-decade synthesis of impact and recovery, Report of Hawaii Coral reef initiative Research Program, Honululu, Hawaii.

Done, T. J. (1982). Patterns in the distribution of coral communities across the central Great Barrier Reef. Coral Reefs, 1, 95-107.

Done, T. J. (1992). Effects of tropical cyclone waves on ecological and geomorphological structures on the Great Barrier Reef. Continental Shelf Research, 12, 859-887.

Done, T. J., \& Navin, K. F. (1990). Vanuatu marine resources: Report of a biological survey. A project of the Australian International Development Assistance Bureau, Townsville, Australia: Australian Institute of Marine Science.

Doty, M. S., \& Oguri, M. (1956). The island mass effect. Journal du Conseil permanent International pour l' Exploration de la Mer, 22, 33-37.

Edmunds, P. J., \& Witman, J. D. (1991). Effect of Hurricane Hugo and the Primary framework of a reef along the south shore of St. John, US Virgin Islands. Marine Ecology Progress Series, 78, 201-204.

Fabricius, K. E., De'ath, G., Puotinen, M. L., Done, T., Cooper, T. F., \& Burgess, S. C. (2008). Disturbance gradients on inshore and offshore coral reefs caused by a severe tropical cyclone. Limnology and Oceanography, 53(2), 690-704.

Farmer, M. W., \& Berg, C. J., Jr. (1989). Circulation around Islands, Gene Flow and Fisheries Management. In 39 Proceedings of the Thirty-Ninth Annual Gulf and Caribbean Fisheries Institute (pp. 318-330). South Carolina, USA: Charleston.

Gardner, T. A., Gill, I. M. C. A., Grant, A., \& Watkinson, A. R. (2005). Hurricanes and Caribbean coral reefs: impacts, recovery patterns, and role in long-term decline. Ecology, 86(1), 174-184.

Glynn, P. W. (1993). Coral reef bleaching: ecological perspectives. Coral Reefs, 12, 1-17.

Grottoli, A. G., Rodrigues, L. J., \& Palardy, J. E. (2006). Heterotrophic plasticity and resilience in bleached corals. Nature, 44, 1186-1189.

Hamner, W. M., \& Hauri, I. R. (1981). Effect of island mass: Water flow and plankton pattern around a reef in Great Barrier Reef lagoon, Australia. Limnology and Oceanography, 26(6), 1084-1102.

Harmelin-Vivien, M. (1994). The effects of storms and cyclones on coral reefs: a review. Journal of Coastal Research, 12, 211-231.

Harmelin-Vivien, M., \& Laboute, P. (1986). Catastrophic impact of hurricanes on atoll outer reef-slopes in Tuamotu (French Polynesia). Coral Reefs, 5, 55-62. 
Hoegh-Gulberg, H., \& Smith, G. J. (1989). The effect of sudden changes in temperature, light and salinity on the population density and export of zooxanthellae from the reef corals Stylophora pistillata Esper and Seriatopora hystrix Dana. Journal of Experimental Marine Biology and Ecology, 129, 279-303.

Hubbard, D. K., Parsons, K. M., Bythell, J. C., \& Walker, N. D. (1991). The effects of hurricane Hugo on the reefs and associated environments of St-Croix US Virgin Islands - A prelimlnary assessment. Journal of Coastal Research, 8, 33-48.

Jokiel, P. L., \& Coles, S. L. (1990). Response of Hawaiian and other Indo-Pacific reef corals to elevated temperature. Coral Reefs, 8, 155-162.

Karlson, R. H., \& Hurd, L. E. (1993). Disturbance, coral reef communities, and changing ecological paradigms. Coral reefs, 12, 117-125.

Krishnan, P., Dam-Roy, S., George, G., Srivastava, R. C., Anand, A., Murugesan, S., et al. (2011). Elevated sea surface temperature during May 2010 induces mass bleaching of corals in the Andaman. Current Science, 100(1), $111-117$.

Krummel, J. R., Gardner, R. H., Sugihara, G., O’neill, R. V., \& Coleman, P. R. (1987). Landscape patterns in a disturbed environment. Oikos, 48, 321-324.

Madin, J., \& Connolly, S. (2006). Ecological consequences of major hydrodynamic disturbances on coral reefs. Nature, 444, 477-480.

Massel, S. R., \& Done, T. J. (1993). Effects of cyclone waves on massive coral assemblages on the Great Barrier Reef: meteorology, hydrodynamics and demography. Coral Reefs, 12, 153-166.

Mumby, P. J. (1999). Bleaching and Hurricane disturbances to populations of coral recruits in Belize. Marine Ecology Progress Series, 190, 27-35.

Palardy, J. E., Grottoli, A. G., \& Matthews, K. S. (2006). Effect of naturally changing zooplankton concentrations on feeding rates of two coral species in the Eastern Pacific. Journal of Experimental Marine Biology and Ecology, 331, 99-107.

Perry, C. T., \& Smithers, S. G. (2006). Taphonomic signatures of turbid-zone reef development: Examples from Paluma Shoals and Lugger Shoal, inshore central Great Barrier Reef, Australia. Palaeogeography Palaeoclimatology Palaeoecology, 242, 1-20.
Petraitis, P. S., Latham, R. E., \& Niesenbaum, R. A. (1989). The maintenance of species diversity by disturbance. Quarterly Reviews in Biology, 64, 393-418.

Pickett, S. T. A., Kolasa, J., Armesto, J., \& Collins, S. L. (1989). The ecological concept of disturbance and its expression at various hierarchical levels. Oikos, 54, 129-136.

Rogers, C. S. (1983). Sublethal and lethal effects of sediments applied to common Caribbean Reef corals in the field. Marine Pollution Bulletin, 14, 378-382.

Rogers, C. S., McLain, L. N., \& Tobias, C. R. (1991). Effects of Hurricane Hugo (1989) on a coral reef in St. John, USVI. Marine Ecology Progress Series, 78, 189-199.

Scoffin, T. P. (1994). History of a fringing reef on the west coast of Barbados 1974-1992. Global aspects of coral reefs. In R. N. Ginsburg (Ed.), Proceedings of the colloquium on global aspects of coral reefs (pp. 273-278).

Sheppard, C. R. C. (1982). Coral populations on reef slopes and their major controls. Marine Ecology Progress Series, 7, 83-115.

Van Woesik, R., Ayling, A. M., \& Mapstone, B. (1991). Impact of tropical cyclone "Ivor" on the Great Barrier Reef, Australia. Journal of Coastal Research, 7, 551-558.

Van Woesik, R., De Vantier, L. M., \& Glazebrook, J. S. (1995). Effects of Cyclone 'Joy' on nearshore coral communities of the Great Barrier Reef. Marine Ecology Progress Series, $128,261-270$.

West, J. M., \& Salm, R. V. (2003). Resistance and resilience to coral bleaching: implications for coral reef conservation and management. Conservation Biology, 17(4), 956-967.

Wiebe, P. H., \& Flierl, G. R. (1983). Euphausid invasion/dispersal in Gulf Stream cold core rings. Australian Journal of Marine \& Freshwater Research, 34, 625-652.

Wilson, S. K., Graham, N. A. J., Pratchett, M. S., Jones, G. P., \& Polunin, N. V. C. (2006). Multiple disturbances and the global degradation of coral reefs: Are reef fishes at risk or resilient? Global Change Biology, 12, 2220-2234.

Woodley, J. D., Chornesky, E. A., Clifford, P. A., Jackson, J. B., Kaufman, L. S., Knowlton, N., et al. (1981). Hurricane Allen's impact on Jamaican coral reefs. Science, 214, 749-755.

Wroblewski, J. J., \& Cheney, J. (1984). Ichthyoplankton associated with a warm core ring off the Scotian shelf. Canadian Journal of Fisheries and Aquatic Sciences, 4, 294-303. 